\title{
Evaluasi Kesuksesan Implementasi Sistem Pengelolaan Aset Desa (SIPADES)
}

\author{
Implementation Success Evaluation of Village Asset Management \\ System (SIPADES)
}

\author{
Mariah Rabiatul Q. ${ }^{1, a)} \&$ M. Raharso ${ }^{1, b)}$ \\ ${ }^{1)}$ Prodi Manajemen Aset, Jurusan Administrasi Bisnis, Politeknik Negeri Bandung, Bandung.
}

Koresponden : ${ }^{a}$ mariah.rabiatul@polban.ac.id \& ${ }^{b}$ mraharso@ polban.ac.id

\begin{abstract}
ABSTRAK
Undang-Undang Desa merupakan salah satu agenda komitmen pemerintah Indonesia dalam pembangunan nasional untuk memperkuat daerah-daerah dan Desa sebagai poros pemerintahan dengan upaya untuk mewujudkan desa yang mandiri, sejahtera, kuat dan demokratis. Pemerintah berupaya untuk memudahkan perangkat desa terkait dengan pengelolaan aset yang transparan dan akuntabel melalui Sistem Pengelolaan Aset Desa (SIPADES) yang melakukan pencatatan administrasi aset tetap desa mulai dari merencanakan pembelian aset tetap hingga kodefikasi dan labelisasi aset tetap yang dimiliki. Hasil observasi yang dilakukan, ditemukan bahwa terdapat beberapa hambatan yang dialami perangkat Desa dalam penggunaan aplikasi SIPADES seperti sistem yang sering error, kurangnya pemahaman perangkat desa dalam penggunaan SIPADES, serta tidak ada pendampingan berkelanjutan jika perangkat Desa menemui kesulitan dalam penggunaan aplikasi. Berdasarkan indikasi masalah tersebut, maka penelitian ini bertujuan untuk mengevaluasi kesuksesan implementasi pengelolaan aset tetap Desa melalui aplikasi SIPADES yang melakukan pengukuran dengan model modifikasi DeLone and McLean tanpa menggunakan variabel use. Penelitian menggunakan pengolahan data kuantitatif deskriptif dengan analisis SEM. Hasil Penelitian diharapkan mampu mengidentifikasi variabel apa saja yang mendukung atau menghambat penerapan sistem informasi pengelolaan aset desa sehingga dimasa mendatang dapat menjadi bahan evaluasi untuk perbaikan maupun peningkatan kualitas system informasi yang digunakan.
\end{abstract}

Kata Kunci : manajemen aset, sistem informasi, pengelolaan aset, evaluasi

\section{PENDAHULUAN}

Salah satu agenda komitmen pemerintah Indonesia dalam pembangunan nasional yaitu mengembangkan daerah-daerah dan desa sebagai poros pemerintahan dengan upaya mewujudkan desa yang sejahtera, mandiri, kuat, dan demokratis. Salah satu bentuk upaya tersebut yaitu dengan memberikan kemudahan kepada perangkat desa untuk melakukan pengelolaan aset tetap desa dengan transparan serta akuntabel dengan menggunakan manajemen aset infrastruktur untuk mempermudah operasional kantor pemerintahan. Manajemen Aset Insfrastruktur adalah tugas, pengetahuan, dan sains untuk mengelola infrastruktur, melalui seluruh siklus hidupnya, agar infrastruktur dapat berfungsi secara berkelanjutan, efektif, efisien dan sesuai dengan berkelanjutan prinsip (Suprayitno \& Soemitro, 2018). Bentuk penggunaan manajemen aset infrastruktur yang lazim digunakan dalam sebuah institusi adalah sistem informasi. 
Sistem informasi berupa Sistem Pengelolaan Aset Desa (SIPADES) yaitu aplikasi yang melakukan pencatatan administrasi aset tetap desa mulai dari merencanakan, mengadakan, penata usahaan hingga penyampaian laporan lengkap dengan kodefikasi dan labelisasi aset tetap berdasarkan aturan yang telah ditetapkan pemerintah. Tujuannya yaitu untuk menertibkan kepemilikan aset dalam upaya meminimalkan resiko kehilangan aset desa dan memberikan kemudahan kepala desa dalam menyajikan laporan aset tetap yang dimiliki kantor desa, serta sebagai sistem informasi yang membantu perangkat desa dalam melakukan tata kelola aset tetap.

Penerapan aplikasi SIPADES diawali terlebih dahulu dengan mengikuti BIMTEK (Bimbingan Teknis) sebagai sarana sosialisasi dan pelatihan penggunaan SIPADES dari pemerintah pusat kepada Desa-Desa. Adapun target dari BIMTEK yang dilakukan terdiri dari beberapa unsur perangkat desa seperti Kepala Desa, Sekretaris Desa, petugas aset Desa, serta BPD sebagai petugas yang mengawasi aset Desa. Dengan adanya BIMTEK diharapkan perangkat desa dapat menggunakan SIPADES sesuai dengan tujuan dan fungsinya dan menjadi sarana dalam mempermudah perangkat desa dalam inventarisasi aset yang dimiliki Desa. Pemerintah Kabupaten Bandung Barat merupakan instansi yang bertangungjawab atas beberapa Kecamatan dan Desa. Setiap Kecamatan terdiri dari beberapa Desa yang mendapatkan BIMTEK SIPADES yang menjadi target pencapaian dari program desa kuat, mandiri, sejahtera, dan demokratis.

Berdasarkan hasil observasi yang dilakukan didapatkan informasi bahwa pengelolaan aset Desa menggunakan dua sistem yaitu pertama sistem manual dengan melakukan pencatatan ke dalam buku yang dilakukan setiap tahun dalam upaya melakukan back-up data aset tetap yang dimiliki Desa. Pencatatan secara manual dilakukan oleh petugas pada unit Tata Usaha dan Umum yang terdiri dari satu orang petugas dan Kepala Urusan yang bertanggungjawab atas kegiatan pengelolaan aset. Bentuk pencatatan kedua berupa sistem digital yaitu melalui aplikasi SIPADES. Penggunaan aplikasi SIPADES dirasakan belum maksimal dikarenakan terdapat beberapa kendala diantaranya yaitu kurangnya pemahaman perangkat Desa dalam mengoperasionalkan sistem SIPADES, aplikasi sering mengalami error ketika mulai digunakan, serta tidak adanya petugas yang secara khusus meng-handle pengelolaan aset melalui aplikasi tersebut dikarenakan pekerjaan yang over load.

Implementasi sistem informasi mempunyai peran strategis dalam operasional perusahaan maupun institusi walaupun dalam pelaksanaannya banyak yang mengalami kegagalan. Dalam banyak penelitian yang diungkapkan Adroni (2017), kesuksesan sebuah sistem informasi direfleksikan dari tingkat kepuasan pemakai (user satisfaction) sistem tersebut. Model DeLone dan McLean (2003) merupakan salah satu rujukan yang banyak digunakan pada penelitian yang mengukur keberhasilan suatu sistem informasi. DeLone dan McLean (2003) menyebutkan bahwa kesuksesan informasi dipengaruhi oleh kualitas informasi, kualitas sistem, kualitas layanan, minat pengguna dalam menggunakan sistem informasi, pemakaian, kepuasan pemakai, dan manfaat bersih.

Artikel ini bertujuan untuk mengevaluasi penerapan aplikasi SIPADES untuk melihat kesuksesan penggunaan sistem informasi pada institusi pemerintah menggunakan pengukuran model modifikasi dari DeLone dan McLean yang telah dimodifikasi.

\section{STUDI PUSTAKA}

Pada umumnya, mayoritas instansi pemerintah maupun swasta telah mempunyai sistem informasi yang bertujuan untuk menunjang kegiatan operasional kerja dimana sistem informasi tersebut terintegrasi dengan penggunaan komputer atau yang dikenal dengan sebutan Computer Based Information System (CBIS). Sistem sebagai kelompok komponen yang saling berhubungan, bekerja bersama untuk mencapai tujuan bersama dengan menerima input serta menghasilkan output dalam proses transformasi yang teratur (O’Brien \& Marakas, 2009). Lebih 
lanjut juga disebutkan bahwa informasi adalah data yang telah dikonversi ke dalam konteks yang bermakna dan berguna bagi pengguna akhir tertentu (O'Brien \& Marakas, 2009). Dari penjelasan tersebut disimpulkan bahwa sistem informasi adalah kombinasi yang teratur dari seperangkat software, hardware, jaringan komunikasi, dan sumber daya data yang mengumpulkan, mengubah, dan menyebarkan informasi dalam sebuah organisasi.

Penggunaan sistem informasi yang baik mampu memberikan dampak kepuasan pengguna dan juga berdampak positif pada organisasi (Wahyuni, 2011). Penggunaan sistem informasi menjadi salah satu bentuk solusi yang efektif dan efisien untuk mempersingkat operasional kerja khususnya pada pendataan aset daerah atau negara. Aset adalah sumber daya ekonomi yang dikuasai dan/atau dimiliki oleh pemerintah sebagai akibat dari peristiwa masa lalu dan dari mana manfaat ekonomi dan/atau sosial di masa depan diharapkan dapat diperoleh, baik oleh pemerintah maupun masyarakat, serta dapat diukur dalam satuan uang, termasuk sumber daya nonkeuangan yang diperlukan untuk penyediaan jasa bagi masyarakat umum dan sumber daya yang dipelihara karena alasan sejarah dan budaya (PP 71/2010 - Lamp. II).

Untuk memastikan aset memiliki nilai tinggi diperlukan sebuah manajeman khusus untuk upaya pengelolaanya dengan proses sistematis yang juga mencakup peningkatan dan penyediaan aset dalam upaya pengambilan keputusan yang efisien (Trojanová, 2014) yang dikenal dengan istilah pengelolaan aset. Pengelolaan barang/aset daerah meliputi: perencanaan kebutuhan dan penganggaran, pengadaan, penerimaan, penyimpanan dan penyaluran, penggunaan, penatausahaan, pemanfaatan, pengamanan dan pemeliharaan, penilaian, penghapusan, pemindah tanganan, pembinaan, pengawasan dan pengendalian, pembiayaan, dan tuntutan ganti rugi (Permendagri 17/2007 - pasal 4 ayat 2). Dalam rangka memberikan kemudahan dalam mengelola aset desa yang akuntabel serta transparan, Direktorat Jenderal Bina Pemerintahan Desa Kementerian Dalam Negeri meluncurkan aplikasi Sistem Pengelolaan Aset Desa atau yang lebih dikenal dengan sebutan SIPADES.

Tujuan penggunaan aplikasi SIPADES adalah sebagai sarana dalam upaya melakukan penertiban kepemilikan aset sesuai dengan peraturan yang berlaku sehingga dapat meminimalkan resiko kehilangan aset desa, menertibkan penggunaan aset yang berdaya guna dan berhasil guna bagi pemerintah dan masyarakat desa, mempermudah kepala desa dalam menyampaikan laporan kekayaan milik desa, dan sebagai alat bantu pemerintah desa dalam tata kelola aset yang dimiliki. Pemerintah mengharapkan penerapan aplikasi SIPADES dapat berhasil secara maksimal dalam pelaksanaannya, namun untuk melihat tingkat kesuksesan penerapan sebuah sistem bukan lah suatu hal yang mudah (Furukawa \& Minami, 2013).

Salah satunya model yang dapat dijadikan rujukan dalam mengukur kesuksesan sistem informasi adalah dengan menggunakan model modifikasi dari DeLone dan McLean (D\&M IS Success Model) yang mengungkapkan bahwa information quality, system quality, dan service quality memiliki pengaruh positif pada use dan user satisfaction yang berdampak positif pada net benefit atau manfaat bersih yang dapat digambarkan sebagai berikut:

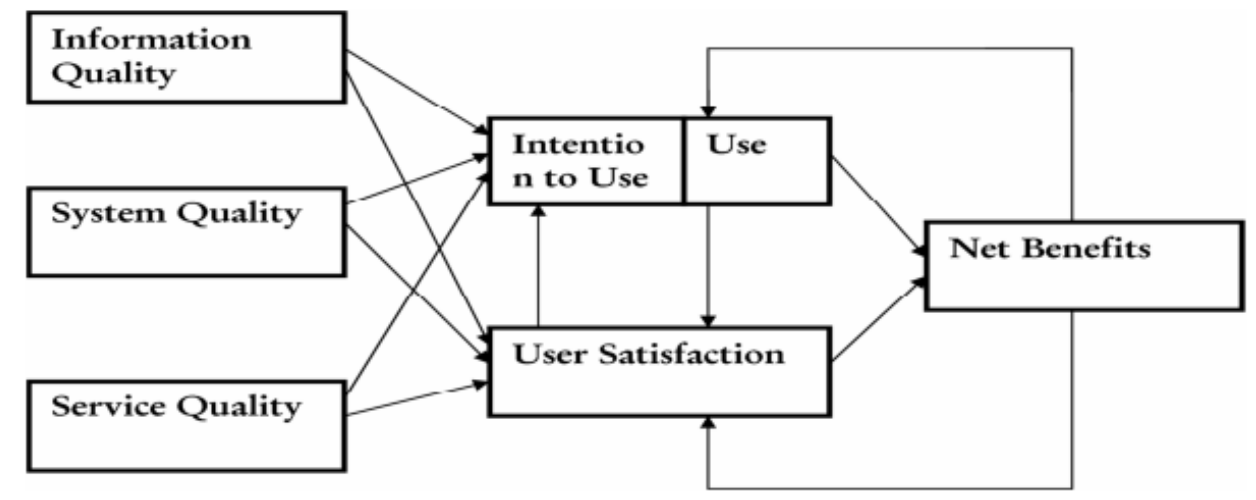

Gambar 1. Model Update Kesuksesan Sistem Informasi DeLone dan McLean (2003) 
Variabel dari model DeLone dan McLean dapat dijabarkan seperti dibawah ini (Saputro et al, 2015) :

- Kualitas Informasi (Information Quality)

Pengukuran kualitas informasi berdasarkan dari sisi pengguna atau penilaian subyektif yang disebut dengan kualitas informasi persepsi (perceived information quality). Pengukuran kualitas informasi menggunakan aspek penilaian (Livari, 2005) yang terdiri dari: ketepatan (precision), kelengkapan (completeness), data yang selalu diperbaharui (currency), keandalan (reliability), dan hasil luaran informasi (format of output).

- Kualitas Sistem (System Quality)

Kualitas system menunjukan kinerja system yang merujuk pada tingkat kemampuan perangkat lunak, perangkat keras, prosedur, serta kebijakan sistem informasi yang menyediakan informasi kebutuhan pengguna (DeLone \& McLean, 2003). Begitu pula dengan kualitas informasi, pengukuran kualitas sistem berdasarkan penilaian subyektif oleh pengguna sehingga disebut dengan kualitas sistem persepsian (perceived system quality). Pengukuran kualitas system menggunakan aspek penilaian (Livari (2005) terdiri dari : integrasi system (system integration), perbaikan kesalahan (error recovery), fleksibilitas sistem (system flexibility), tingkat kenyamanan aksesibilitas (convinience of access), Bahasa yang digunakan (language), dan waktu respon (time to respon).

- Kualitas Layanan (Service Quality)

Kualitas layanan adalah perbandingan ekspektasi pengguna dengan realita dari layanan yang mereka terima. Ada tiga faktor yang mempengaruhi kualitas layanan (DeLone \& McLean, 2003) terdiri dari: sistem empati (system empathy) yaitu kepedulian sistem terhadap pengguna, system responsiveness yaitu kualitas umpan balik sistem terhadap aksi yang dilakukan oleh pengguna, serta jaminan (assurance) yaitu jaminan kualitas yang diberikan sistem.

- Penggunaan (Use)

Livari (2005) menggunakan dua aspek untuk melakukan pengukuran penilaian penggunaan yang terdiri dari: frekuensi tingkat penggunaan (frequency of use) yaitu seberapa sering sistem digunakan untuk melakukan pengolahan informasi dan penggunaan waktu harian (daily used time).

- Kepuasan Pengguna (User Satisfaction)

Kepuasan pengguna terhadap sistem informasi adalah kriteria subjektif yang mengukur tingkat kesukaan pengguna dalam menggunakan sistem. Penelitian ini mengadopsi indikator dari variabel kepuasan pengguna berdasarkan penelitian dari DeLone \& McLean (2003) yang terdiri dari dua indikator, yaitu:

a. Kepuasan Informasi (Repeat Purchase)

Kepuasan informasi adalah perbandingan dari tingkat harapan pengguna atau kebutuhan sistem informasi dengan kinerja sistem aktual yang diterima.

b. Kepuasan Menyeluruh (Repeat Visit)

Bentuk dari kepuasan secara global atas semua sistem yang disajikan dan tingkat kepuasan layanan informasi dan sistem. Serta manfaat yang diterima dalam proses input dan proses output informasi.

- Hasil bersih yang Didapat (Net Benefit)

Net benefit adalah manfaat bersih yang dirasakan oleh individu dan organisasi setelah menggunakan sistem informasi. Penelitian ini menggunakan lima item dari enam item yang diadaptasi dari penelitian Davis (1989) untuk mengukur persepsi kegunaan (perceived usefulness) yang terdiri dari: job performance, ease of job, effectiveness, speed of acomplishing task, dan usefullness in work. 
Penelitian bertujuan mengevaluasi factor kesuksesan SIPADES sebagai suatu system informasi aset tetap desa menggunakan modifikasi model dari DeLone \& McLean (2003) dengan mengeluarkan variable intention to use(intensitas penggunaan) dan use (penggunaan) karena aplikasi SIPADES merupakan Decision Supporting System (DSS) mandatory di kantor desa setingkat Kabupaten seluruh Indonesia. DSS merupakan sistem informasi yang digunakan manajer dalam membantu pengambilan keputusan setengah-terstruktur agar lebih efektif .

Penelitian Livari (2005) pada sistem informasi Akuntansi di pemerintahan Finlandia menunjukkan bahwa kualitas informasi tidak berpengaruh pada penggunaan system informasi. Sistem informasi yang bersifat mandatory tidak bisa dijadikan acuan dalam menguji kepuasan pengguna terhadap sistem informasi. Tidakpuasaan pengguna disebabkan karena kepuasan merupakan sikap yang muncul dari dalam diri dan tidak dapat dipaksakan. Berdasarkan hal tersebut, maka variabel yang dapat menjadi faktor kesuksesan sistem informasi pengelolaan aset desa (SIPADES) terletak di kualitas informasi yang merupakan hasil output sistem, kualitas sistem dan kualitas layanan. Variabel kepuasan pengguna pada akhirnya akan memberikan pengaruh pada manfaat bersih yang terbagi menjadi dampak individu dan dampak bagi organisasi, sehingga kerangka pemikirannya adalah sebagai berikut:

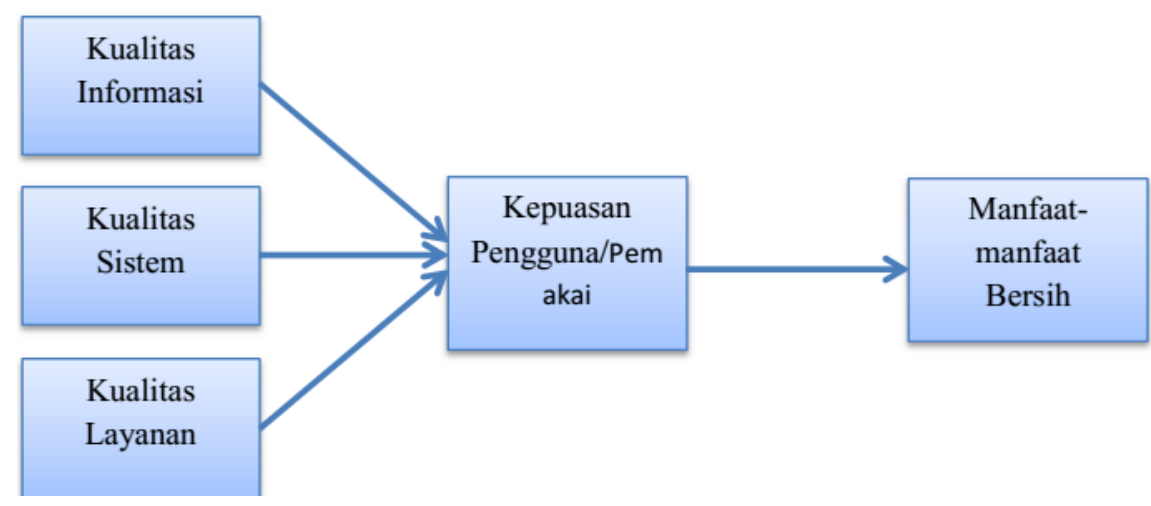

Gambar 2. Kerangka Pemikiran

Sumber: Model IS (DeLone \& Mclean 2003)

\section{Hipotesis Penelitian}

Penelitian ini bertujuan untuk mengevaluasi faktor kesuksesan SIPADES sebagai suatu sistem informasi dengan menggunakan modifikasi model dari DeLone \& McLean (2003). Oleh karena itu diperlukan 5 pengujian hipotesis sesuai dengan model penelitian yang digunakan yang terdiri dari :

Hipotesis 1

Ho : Kualitas informasi tidak berpengaruh terhadap kepuasan pengguna

H1 : Kualitas informasi berpengaruh terhadap kepuasan pengguna

Hipotesis 2

Ho : Kualitas sistem tidak berpengaruh terhadap kepuasan pengguna

H1 : Kualitas sistem berpengaruh terhadap kepuasan pengguna

Hipotesis 3

Ho : Kualitas sistem tidak berpengaruh terhadap kepuasan pengguna

H1 : Kualitas layanan berpengaruh terhadap kepuasan pengguna

Hipotesis 4

Ho : Kualitas informasi, kualitas layanan, kualitas sistem secara bersama tidak berpengaruh terhadap kepuasan pengguna

H1 : Kualitas informasi, kualitas layanan, dan kualitas sistem secara bersama berpengaruh terhadap kepuasan pengguna 


\section{Hipotesis 5}

Ho : Kepuasan pengguna tidak berpengaruh terhadap manfaat-manfaat bersih

H1 : Kepuasan pengguna berpengaruh terhadap manfaat-manfaat bersih

\section{PENGUMPULAN DATA}

Data didapatkan dari observasi awal dengan melakukan wawancara untuk mendapatkan fenomena yang terjadi di kantor desa wilayah Kabupaten Bandung Barat terkait dengan penerapan aplikasi sistem informasi pengelolaan aset desa. Selain itu dilakukan penyebaran angket/kuesioner yang diisi oleh perangkat Desa di lingkungan kantor Desa wilayah Kabupaten Bandung Barat yang telah mendapatkan bimbingan teknis mengenai penggunaan aplikasi SIPADES maupun yang menjadi pengguna aplikasi SIPADES. Analisa deskriptif digunakan untuk menggambarkan ataupun mendeskripsikan informasi maupun data yang telah dikumpulkan sebagaimana adanya tanpa maksud membuat kesimpulan yang berlaku untuk umum atau generalisasi (Sugiyono, 2014). Analisis dilakukan menggunakan model persamaan struktural (Structural Equation Model/SEM) dengan menggunakan tools SMARTPLS. Menurut Latan \& Gudono (2012:1), SEM merupakan alat untuk menganalisis data multivariat, terutama dalam melakukan pengujian hubungan kausalitas (sebab akibat).

\section{ANALISIS PENELITIAN}

Analisis penelitian ini menggunakan dua jenis evaluasi yaitu evaluasi model pengukuran/measurement (outer) model dan evaluasi model struktural/structural (inner) model

\section{A. Measurement (outer) model}

Evaluasi model pengukuran yang digunakan menggunakan tiga tahap yang terdiri dari:

1. Validitas Konvergen (convergent validity)

Validitas konvergen dinilai berdasarkan korelasi antara skor item atau component score dengan skor variabel laten atau construct score yang dihitung dengan PLS. Minimal loading factor pada penelitian berbasis SEM adalah 0,6 pada sample kurang dari 100. Hasil pengujian menunjukan ada beberapa indikator yang faktor loadingnya $\leq 0,6$. Hasil ini mengindikasikan indikator tersebut memberikan kontribusi lebih rendah dari $60 \%$ pada variable atau konstruk nya. Dengan demikian perlu dilakukan dropping karena tidak memenuhi nilai minimal faktor dan dilakukan estimasi ulang. Hasil pengujian ulang, disampaikan di Tabel 1 sebagai berikut.

Tabel 1.a Faktor Loading Hasil Dropping

\begin{tabular}{|l|c|c|}
\hline Variabel/Konstruk & Indikator & Faktor Loading \\
\hline \multirow{4}{*}{ Kualitas Informasi } & KI1 & 0.6435 \\
\cline { 2 - 3 } & KI2 & 0.7646 \\
\cline { 2 - 3 } & KI3 & 0.8387 \\
\cline { 2 - 3 } & KI4 & 0.8682 \\
\hline \multirow{4}{*}{ Kualitas Sistem } & KI5 & 0.7092 \\
\cline { 2 - 3 } & KS2 & 0.6413 \\
\hline \multirow{3}{*}{ Kualitas Layanan } & KS3 & 0.7715 \\
\cline { 2 - 3 } & KS4 & 0.6853 \\
\cline { 2 - 3 } & KS6 & 0.7402 \\
\cline { 2 - 3 } & KL1 & 0.7136 \\
\cline { 2 - 3 } & KL2 & 0.6694 \\
\hline
\end{tabular}


Tabel 1.b Faktor Loading Hasil Dropping

\begin{tabular}{|l|c|c|}
\hline Variabel/Konstruk & Indikator & Faktor Loading \\
\hline \multirow{3}{*}{ Kepuasan Pengguna } & KP1 & 0.8201 \\
\cline { 2 - 3 } & KP2 & 0.7354 \\
\hline \multirow{3}{*}{ Manfaat Bersih } & MB1 & 0.6159 \\
\cline { 2 - 3 } & MB2 & 0.7473 \\
\cline { 2 - 3 } & MB3 & 0.6893 \\
\cline { 2 - 3 } & MB4 & 0.7239 \\
\cline { 2 - 3 } & MB5 & 0.8376 \\
\hline
\end{tabular}

Tabel 1 menunjukan bahwa semua indikator penilaian sudah memenuhi minimal nilai faktor loading yaitu $\geq 0,6$ yang berarti semua indikator yang diujikan memenuhi syarat.

2. Validitas Diskriminan (Discriminant validity)

Salah satu cara melakukan pengujian validitas diskriminan yaitu dengan melihat akar kuadrat dari Average Variance Extracted (AVE) besaran setiap konstruk dibandingkan dengan korelasi antara konstruk satu dengan konstruk lainnya. Pengujian nya dengan cara menghitung nilai dari AVE untuk setiap model dengan nilai minimal AVE utnuk penelitian berbasis SEM adalah 0.5. Berikut ini hasil perhitungan nilai AVE:

Tabel 2. Nilai AVE dan Akar Kuadrat AVE

\begin{tabular}{|l|c|c|}
\hline Konstruk & AVE & $\begin{array}{c}\text { Akar Kuadrat } \\
\text { AVE }\end{array}$ \\
\hline Kualitas Informasi & 0.6769 & 0.8227 \\
\hline Kualitas sistem & 0.6055 & 0.7781 \\
\hline Kualitas layanan & 0.5790 & 0.7609 \\
\hline Kepuasan pengguna & 0.6644 & 0.8151 \\
\hline Manfaat bersih & 0.6228 & 0.7892 \\
\hline
\end{tabular}

Tabel 2 menunjukan hasil nilai AVE terkecil sebesar 0.5790. Nilai ini sesuai syarat bahwa nilai AVE setiap konstruk adalah $\geq 0.5$. Pengujian ini menunjukan bahwa hasil perhitungan memenuhi syarat uji validitas diskriminan.

3. Composite Reliability

Langkah selanjutnya dalam melakukan evaluasi outer model yaitu melihat nilai reliabilitas konstruk variabel laten dengan menggunakan dua kriteria yaitu composite reliability dan cronbach alpha. Syarat minimal nilai yang harus dipenuhi adalah 0.7 untuk memenuhi syarat uji composite reliability. Berikut hasil pengujian dari SmartPLS:

Tabel 3. Composite Reliability dan Cronbachs Alpha

\begin{tabular}{|l|c|c|}
\hline Konstruk & $\begin{array}{c}\text { Composite } \\
\text { Reliability }\end{array}$ & $\begin{array}{c}\text { Cronbachs } \\
\text { Alpha }\end{array}$ \\
\hline Kualitas Informasi & 0.8858 & 0.8471 \\
\hline Kualitas sistem & 0.8585 & 0.7768 \\
\hline Kualitas layanan & 0.8722 & 0.8300 \\
\hline Kepuasan pengguna & 0.8548 & 0.7543 \\
\hline Manfaat bersih & 0.9099 & 0.8950 \\
\hline
\end{tabular}

Tabel 3 menunjukan bahwa nilai composite reliability dan nilai cronbach alpha berada diatas 0,70. Hasil tersebut menunjukan bahwa semua konstruk reliable. Keseluruhan uji validitas yang dilakukan menyatakan bahwa data kuisioner bersifat valid dan reliabel. 


\section{B. Structural Inner Model}

Penilaian model struktural dilihat dari nilai $R$-square $(R 2)$ untuk melihat pengaruh variabel laten independen tertentu terhadap variabel laten dependen. Dibawah ini adalah perhitungan $R$-square :

Tabel 4. $R$-Square Pada Konstruksi

\begin{tabular}{|l|c|}
\hline Konstruk & $\boldsymbol{R}$-Square \\
\hline Kepuasan pengguna & 0.5351 \\
\hline Manfaat bersih & 0.4972 \\
\hline
\end{tabular}

Tabel 4 menunjukan hasil variabel dependen kepuasan pengguna memiliki nilai $r$-square 0,5751. Hal ini sesuai dengan syarat nilai minimal 0,52 yang menginterpretasikan bahwa variabel bebas memberikan pengaruh pada kategori cukup terhadap kepuasan pengguna. Sedangkan variabel kepuasan pengguna memiliki nilai hasil pengujian R-square sebesar 0.4972 dengan arti variabel bebas kepuasan pengguna memberikan pengaruh pada kategori cukup terhadap manfaat bersih yang dihasilkan oleh aplikasi SIPADES.

\section{Pembahasan Hasil Penelitian}

Hasil analisa deskriptif menunjukan bahwa setiap variabel mulai dari variabel kualitas informasi, kualitas layanan, kepuasan pengguna, sampai pada variabel manfaat bersih mendapatkan prosentasi diatas $68 \%$ yang menunjukan bahwa responden menjawab kualitas informasi dan kualitas layanan SIPADES sudah baik. Untuk variable kualitas sistem responden menjawab kurang baik dengan prosentase dibawah $68 \%$.

\section{Uji Hipotesis}

Uji hipotesis dilakukan dengan cara Bootstrapping untuk menghitung nilai kesalahan standar, koefisien jalur, dan nilai dari T-Statistik. Adapun hasil pengujian bootstrapping disampaikan pada Tabel 5 sebagai berikut.

Tabel 5. Hasil Bootstrapping

\begin{tabular}{|l|c|c|c|c|c|c|}
\hline Hubungan Variabel & $\begin{array}{c}\text { Original } \\
\text { Sample } \\
(\mathbf{o})\end{array}$ & $\begin{array}{c}\text { Sample } \\
\text { Mean } \\
(\mathbf{M})\end{array}$ & $\begin{array}{c}\text { Standard } \\
\text { Deviation } \\
\text { (STDEV) }\end{array}$ & $\begin{array}{c}\text { Standard } \\
\text { Error } \\
\text { (STERR) }\end{array}$ & $\begin{array}{c}\text { T } \\
\text { Statistics }\end{array}$ & $\begin{array}{c}\text { P } \\
\text { Value }\end{array}$ \\
\hline $\begin{array}{l}\text { Kualitas informasi -> } \\
\text { Kepuasan pengguna }\end{array}$ & 0.4864 & 0.4885 & 0.0927 & 0.0927 & 5.2450 & 0.0000 \\
\hline $\begin{array}{l}\text { Kualitas sistem -> Kepuasan } \\
\text { pengguna }\end{array}$ & 0.1549 & 0.1520 & 0.0731 & 0.0731 & $2 . .193$ & 0.0343 \\
\hline $\begin{array}{l}\text { Kualitas layanan -> } \\
\text { Kepuasan pengguna }\end{array}$ & 0.0594 & 0.0767 & 0.1318 & 0.1318 & 0.4508 & - \\
\hline $\begin{array}{l}\text { Kepuasan pengguna -> } \\
\text { Manfaat bersih }\end{array}$ & 0.6410 & 0.6600 & 0.0685 & 0.0685 & 9.3589 & 0.0000 \\
\hline
\end{tabular}

Pada tabel 5 terdapat nilai T-Statistik yang berguna untuk membuktikan pengujian hipotesis yang telah diajukan sebelumnya. Uji hipotesis pada variabel kualitas informasi menggunakan perbandingan T-Statistik variabel kualitas informasi dengan T-Tabel. Berikut ini hasil pengujian hipotesis : 
Tabel 6. Hasil Rekapitulasi Uji Hipotesis

\begin{tabular}{|c|c|c|c|}
\hline \multicolumn{2}{|r|}{ Hipotesis } & Hasil & Signifikansi \\
\hline $\mathrm{H} 1$ & $\begin{array}{l}\text { Ho : Kualitas informasi tidak berpengaruh terhadap kepuasan } \\
\text { pengguna }\end{array}$ & Ditolak & $\mathrm{p} \leq 0,001$ \\
\hline $\mathrm{H} 2$ & $\begin{array}{l}\text { Ho : Kualitas sistem tidak berpengaruh terhadap kepuasan } \\
\text { pengguna }\end{array}$ & Ditolak & $\mathrm{p} \leq 0,05$ \\
\hline $\mathrm{H} 3$ & $\begin{array}{l}\text { Ho : Kualitas Layanan tidak berpengaruh terhadap kepuasan } \\
\text { pengguna } \\
\mathrm{H}_{1}: \text { Kualitas Layanan berpengaruh terhadap kepuasan } \\
\text { pengguna }\end{array}$ & $\begin{array}{c}\text { Tidak } \\
\text { Ditolak }\end{array}$ & $\begin{array}{c}\text { Tidak } \\
\text { Ditolak }\end{array}$ \\
\hline $\mathrm{H} 4$ & \begin{tabular}{|c|} 
Ho : $\begin{array}{l}\text { Kualitas informasi, kualitas layanan, dan kualitas } \\
\text { sistem secara bersama tidak berpengaruh terhadap } \\
\text { kepuasan pengguna }\end{array}$ \\
$\mathrm{H}_{1}: \begin{array}{l}\text { Kualitas informasi, kualitas layanan, dan kualitas } \\
\text { sistem secara bersama berpengaruh terhadap } \\
\text { kepuasan pengguna }\end{array}$
\end{tabular} & Ditolak & Ditolak \\
\hline $\mathrm{H} 5$ & $\begin{array}{l}\text { Ho : Kepuasan pengguna tidak berpengaruh terhadap } \\
\text { manfaat bersih }\end{array}$ & Ditolak & $\mathrm{p} \leq 0,001$ \\
\hline
\end{tabular}

\section{KESIMPULAN}

Hasil pengolahan data dapat disimpulkan bahwa penerapan aplikasi SIPADES sebagai tools dalam melakukan pengelolaan aset desa terbukti cukup baik dengan diperolehnya nilai Rsquare 0.53 untuk pengaruh variabel kepuasan pengguna terhadap variabel kualitas informasi, kualitas sistem, dan kualitas layanan. Sedangkan variabel kepuasan pengguna memiliki pengaruh cukup baik terhadap variabel manfaat bersih dengan nilai r-square sebesar 0.49.

Hasil lain yang didapatkan adalah variabel kualitas layanan tidak memberikan pengaruh yang signifikan terhadap kepuasan pengguna, hal ini terjadi karena masih kurangnya pemahaman perangkat desa terhadap cara penggunaan aplikasi SIPADES yang dianggap terlalu kompleks untuk diterapkan pada kantor desa. Bimbingan teknik yang diberikan tidak bisa menjangkau seluruh perangkat desa yang terlibat langsung dalam menggunakan aplikasi SIPADES karena bimbingan teknis penggunaan aplikasi hanya diberikan kepada Kepala Desa, Sekertaris Desa, atau Kepala Urusan Tata Usaha dan Umum, padahal kenyataan dilapangan seringkali yang menggunakan aplikasi SIPADES adalah staf umum ataupun staf honorer. Kompleksnya aplikasi SIPADES juga tidak diimbangi dengan pendampingan khusus untuk membantu perangkat desa yang menemui kesulitan dalam penggunaan aplikasi.

Hal tersebut dapat diatasi dengan adanya bimbingan teknis bertahap dan tepat sasaran untuk perangkat desa yang melakukan pengelolaan aset dengan aplikasi SIPADES, tidak hanya kepada perangkat desa yang memiliki jabatan tetapi kepada staf perangkat desa yang memiliki 
jobdesk untuk melakukan pencatatan pengelolaan aset. Selain itu perlu ada evaluasi rutin berupa pendampingan secara berkala untuk memfasilitasi perangkat desa yang memiliki kesulitan dalam menggunakan aplikasi SIPADES. Untuk penelitian selanjutnya meneliti variabel manfaat bersih dengan berfokus pada variabel kinerja individu dan variabel manfaat organisasi. Pemisahan variabel tersebut dapat menjadi suatu penelitian yang memberikan informasi mengenai pengaruh sistem informasi terhadap kinerja individu maupun manfaat organisasi dengan lebih rinci.

\section{DAFTAR PUSTAKA}

Adroni, Nadif. \& Sitorus, Palti Marulitua. (2017). "Evaluation of Badix Information System Implementation Success in Telkomsel Region of Sumbagsel Using DeLone \& McLean Model". International Journal of Business and Economic Affair. Vol 2 (3): 211-219.

Davis, F.D. (1989). "Perceived Ease of Use, and User Acceptance of Information Technology”. MIS Q. Vol. 13(3): 319-340.

DeLone, W.H. \& McLean, E.R. (2003). "The DeLone and McLean Model of Information Systems Success: A Ten-Year Update". Journal of Management Information System. Vol. 19(4): 9-30.

Furukawa, M. \& Minami, A. (2013). "A Study on the 'Flexibility' of Information Systems (Part 1): Why Do They Need to Be Flexible?”. International Journal of Bussiness Management. Vol. 8(20): 48-61.

Latan, H \& Gudono. (2012). SEM-Structural Equation Modeling Aplikasi Software Tetrad IV. Edisi Pertama. Penerbit BPFE, Fakultas Ekonomi dan Bisnis. Universitas Gajah Mada. Yogyakarta.

Livari, J. (2005). "An Empirical Test of the Model of Information System Success". DATA BASE Adv. Information System. Vol. 36(2): 8-27.

O'Brien, J.A. \& Marakas, G.M. (2009). Management Information Systems ( $9^{\text {th }}$ Edition). McGraw-Hill. New York.

Permendagri 17/2007. Permendagri Nomor 17 Tahun 2007 tentang Pedoman Teknis Pengelolaan Barang Milik Daerah.

PP 71/2010. Peraturan Pemerintah No. 71 Tahun 2010 tentang Standar Akutansi Pemerintah. Saputro, P.H., Budiyanto, A.D. \& Santoso, A.J. (2015). "Model DeLone and McLean Untuk Mengukur Kesuksesan E-government Kota Pekalongan”. Scientific Journal of Informatics. Vol.2, No. 1.

Sugiyono. (2014). Metode Penelitian Kombinasi (Mixed Methods). Alfabeta. Bandung.

Suprayitno, H. \& Soemitro, R.A.A. (2018). "Preliminary Reflexion on Basic Principal of Infrastructure Asset Management". Jurnal Manajemen Aset Infrastruktur \& Fasilitas, Vol. 2, No. 1, Maret 2018, Hal. : 1-9.

Trojanová, M. (2014). “Asset Management As Integral Part Of Road Economy”. Proceedia Engineering, 91(TFoCE), 481-486. https://doi.org/10.1016/j.proeng.2014.12.030.

Wahyuni, T. (2011). "Uji Empiris Model Delone dan Mclean Terhadap Kesuksesan Sistem Informasi Manajemen Daerah (SIMDA)". Jurnal Badan Pendidik dan Pelatih Keuangan. Vol. 2 (99): 4-24. 